\title{
PENYULUHAN TENTANG COVID-19 DAN TATA LAKSANANYA DI KECAMATAN MANGGALA KOTA MAKASSAR
}

\author{
Anita, Darmawaty Rauf, Suardi
}

Program Studi D3 Teknologi Laboratorium Medis, Politeknik Kesehatan Muhammadiyah Makassar E-mail: anitadinar1983@gmail.com

\begin{abstract}
Coronaviruses are a group of viruses that cause respiratory disorders caused by the Sars-CoV-2 virus that has never been previously identified in humans. COVID-19 can be transmitted through coughing/sneezing droplets from human to human. Therefore, standard recommendations as a preventive measure for COVID-19 transmission must be carried out as early as possible, which can be carried out by providing health education to the community through community service activities at Al-Hidayah Perumnas Antang Makassar City. Knowledge of how to avoid COVID-19 disease and health maintenance will automatically increase public knowledge. The public's knowledge and understanding of the corona virus can be interpreted as the result of knowing the public about how to prevent, treat and treat complications. The purpose of this counseling is to increase the understanding of the congregation of Mesjdi Al-Hidayah Perumnas Antang Makassar City regarding COVID-19 and its management. The method used in this counseling is a lecture and discussion method involving interaction between participants and the extension team. From this counseling activity, it is hoped that there will be an increase in the understanding of counseling participants about COVID-19 and its management. From this community service activity, it can be concluded that the extension participants have increased understanding of COVID-19 and its management starting with prevention, treatment and complications
\end{abstract}

Keywords: COVID-19. Mesjid Al-Hidayah, Perumanas Antang . Makassar.

\begin{abstract}
Abstrak
Coronavirus adalah kelompok virus penyebab penyakit gangguan pernapasan yang disebabkan oleh virus Sars-CoV-2 yang belum pernah teridentifikasi sebelumnya pada manusia. COVID-19 dapat ditularkan melalui percikan batuk/bersin (droplet) dari manusia ke manusia.Oleh karena itu, rekomendasi standar sebagai langkah pencegahan penularan COVID-19 wajib dilakukan sedini mungkin, yang dapat dilaksanakan dengan penyuluhan kesehatan kepada masyarakat melalui kegiatan pengabdian kepada jamaah Mesjdi Al-Hidayah Perumnas Antang Kota Makassar. Pengetahuan mengenai cara menghindari penyakit COVID-19 dan pemeliharaan kesehatan, dengan sendirinya akan meningkatkan pengetahuan masyarakat. Pengetahuan dan pemahaman masyarakat tentang virus corona dapat diartikan sebagai hasil tahu masyarakat mengenai cara pencegahan, pengobatan dan komplikasinya. Tujuan dilakukan penyuluhan ini adalah untuk meningkatkan pemahaman jamaah Mesjdi Al-Hidayah Perumnas Antang Kota Makassar mengenai COVID-19 dan tatalaksananya. Metode yang digunakan dalam penyuluhan ini adalah metode ceramah dan diskusi dengan melibatkan interaksi antara peserta dan tim penyuluh.Dari kegiatan penyuluhan ini diharapkan terjadi peningkatan pemahaman peserta penyuluhan mengenai COVID-19 dan tata laksananya .Dari kegiatan pengabdian masyarakat ini dapat disimpulkan bahwa peserta penyuluhan mengalami peningkatan pemahaman mengenai COVID-

dan tata laksananya .Dari kegiatan pengabdian masyarakat ini dapat disimpulkan bahwa peserta penyuluhan mengalami peningkatan pemahaman mengenai COVID-19 dan tata laksananya dimulai dari cara pencegahan, pengobatan dan komplikasinya.
\end{abstract}

Keywords: COVID-19. Mesjid Al-Hidayah, Perumanas Antang . Makassar 


\section{PENDAHULUAN}

Coronavirus adalah kelompok virus penyebab penyakit gangguan pernapasan, mulai dari gejala ringan hingga berat.Coronavirus Disease 2019 (COVID-19) adalah penyakit jenis baru yang disebabkan oleh virus Sars-CoV-2 yang belum pernah teridentifikasi sebelumnya pada manusia.Hingga saat ini hewan yang menjadi transmisi perantara sumber penularan COVID-19 masih belum diketahui ${ }^{1}$.

Gejala umum infeksi COVID-19 menyerupai gejala flu biasa seperti gangguan pernapasan akut, demam disertai batuk dan sesak napas. Masa inkubasi rata-rata 5-6 hari dengan masa inkubasi terpanjang 14 hari.Pada kasus COVID-19 yang berat dapat menyebabkan pneumonia, sindrom pernapasan akut, gagal ginjal, dan bahkan kematian.Tanda-tanda dan gejala klinis yang dilaporkan pada sebagian besar kasus adalah demam, dengan beberapa kasus mengalami kesulitan bernapas, dan hasil rontgen menunjukkan infiltrat pneumonia luas di kedua paru1.

Kasus COVID-19 di Indonesia mulai teridentifikasi pada tanggal 17 Maret 2020 dengan kasus yang terinfeksi sebanyak 172 orang, sedangkan angka kematian sebanyak 55 orang ${ }^{2}$. Dalam perkembangan selanjutnya per tanggal 31 Maret 2020 kasus corona virus mengalami peningkatan diangka 1.528 orang dengan jumlah kematian sebanyak 136 orang 3 .Oleh karena itu WHO pada Maret 2020 mendesak berbagai negara termasuk Indonesia untuk melakukan berbagai upaya dan langkah efektif untuk mengendalikan laju peningkatan jumlah kasus penularan COVID-194.

Berdasarkan hasil penelitian, COVID-19 dapat ditularkan melalui percikan batuk/bersin (droplet) dari manusia ke manusia, tidak melalui udara.Orang yang kontak erat dengan pasien COVID-19 memiliki resiko tertular penyakit ini.Oleh karena itu, rekomendasi standar sebagai langkah pencegahan penularan COVID-19 wajib dilakukan sedini mungkin.

Undang-Undang No.6 Tahun 2018 tentang Kekarantinaan Kesehatan, merekomendasikan standar langkah pencegahan penularan COVID-19 dengan menjaga kebersihan tangan secara rutin melalui aktifitas cuci tangan secara teratur menggunakan sabun dan air bersih, menerapkan etika batuk dan bersin, kewajiban pemakaian masker, perlunya pembatasan kegiatan sosial oleh masyarakat, menghindari kontak dekat dengan siapapun yang menunjukkan gejala penyakit pernapasan seperti batuk dan bersin $1,5,6,7$.

Pengetahuan mengenai cara menghindari penyakit dan pemeliharaan kesehatan, dengan sendirinya meningkatkan pengetahuan masyarakat ${ }^{8}$. Pengetahuan dan pemahaman masyarakat tentang virus corona dapat diartikan sebagai hasil tahu masyarakat mengenai cara pencegahan, pengobatan dan komplikasinya ${ }^{9}$.Hal ini memiliki peranan penting karena pengetahuan akan membentuk kepercayaan dalam mempersepsikan kenyataan, memberikan dasar bagi 
pengambilan keputusan serta penentuan perilaku akan suatu objek ${ }^{10}$, sehingga punya pengaruh terhadap perilaku seseorang.

Berdasarkan hasil observasi yang dilaksanakan oleh tim penyuluh, sebelum dilaksanakan kegiatan ini, ditemukan data bahwa masih minimnya pengetahuan dan pemahaman masyarakat di sekitar Mesjid Al- Hidayah Perumnas Antang Kota Makassar mengenai COVID-19.Umumnya masyarakat masih abai dalam menerapkan upaya -upaya pencegahan untuk menurunkan laju penularan COVID-19 seperti masih rendahnya pemahaman mengenai virus corona, masih rendahnya pemahaman prilaku cuci tangan dengan air bersih secara teratur serta masih minimnya kepatuhan menggunakan masker.

Oleh karena itu dilakukanlah kegiatan pengabdian masyarakat yang merupakan salah satu pengejawantahan pelaksanaan Tridharma Perguruan Tinggi Program Studi D3 Teknologi Laboratorium Medis, Politeknik Kesehatan Muhammadiyah Makassar, melalui edukasi penyuluhan kepada masyarakat di Mesjid Al- Hidayah Perumnas Antang Kota Makassar mengenai COVID-19 dan Penatalaksanaannya.

\section{METODE}

Metode yang digunakan dalam kegiatan penyuluhan ini adalah :

1. Metode ceramah dilaksanakan pada awal kegiatan penyuluhan dengan menggunakan fasilitator pada saat menyampaikan materi secara verbal.

2. Metode diskusi yang dilaksanakan ini membutuhkan interaksi antara peserta penyuluhan dengan fasilitator materi untuk saling bertukar informasi secara lisan dan berhadapan.Metode ini dilaksanakan dengan tujuan agar peserta penyuluhan memahami lebih mendalam materi yang diberikan.

\section{HASIL DAN PEMBAHASAN}

Pengabdian kepada masyarakat adalah salah satu usaha untuk menyebarluaskan ilmu pengetahuan dan teknologi, kepada masyarakat.Melalui kegiatan pengabdian diharapkan terjadi perubahan bagi individu/masyarakat baik jangka pendek maupun jangka panjang.

Pada kegiatan penyuluhan ini dilaksanakan dengan metode ceramah dengan memberikan pemahaman mengenai COVID-19 dan penatalaksanaanya kepada masyarakat di Mesjid Al Hidayah Perumnas Antang, Kota Makassar.Kegiatan penyuluhan ini melibatkan fasilitator dari Dosen maupun mahasiswa Program Studi Teknologi Laboratorium Medis, Politeknik Kesehatan Muhammadiyah Makassar. 


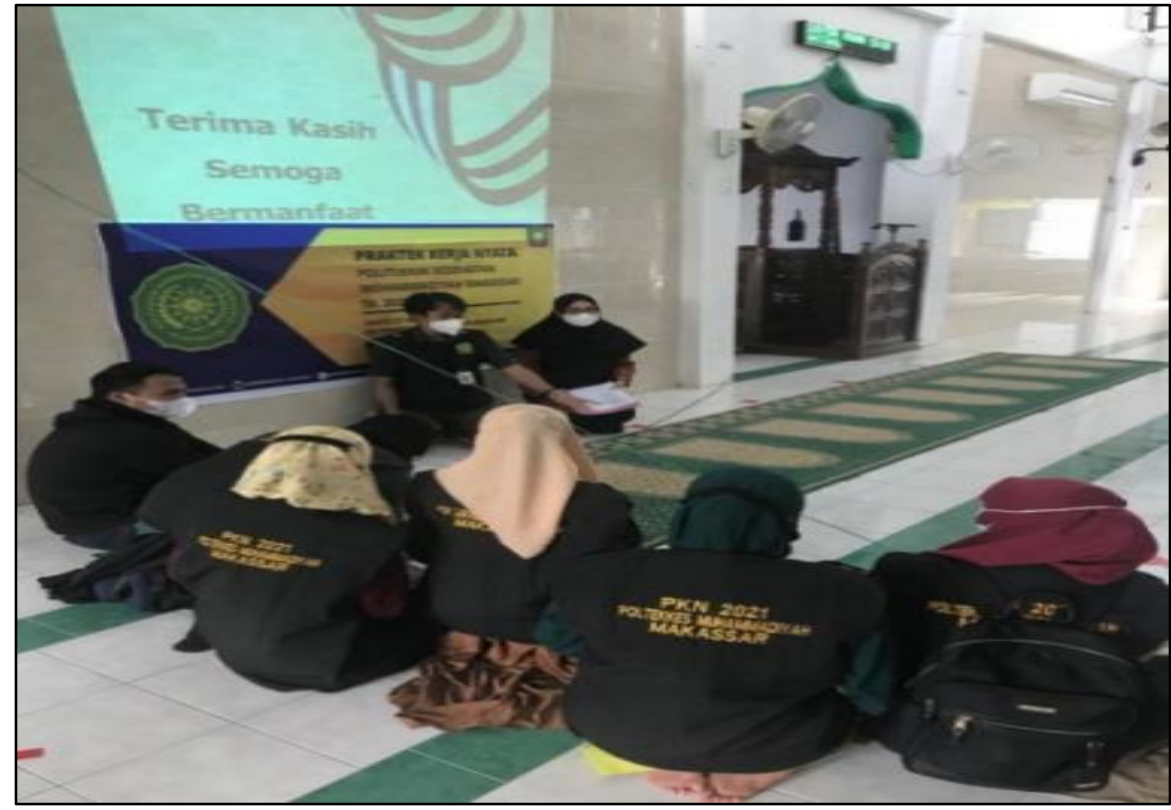

Gambar 1. Tim Penyuluh

Pada kegiatan penyuluhan ini dijelaskan mengenai COVID-19 yang merupakan penyakit varian coronavirus baru. Gejala COVID-19 mirip dengan influenza atau batuk pilek berupa demam disertai batuk dan sesak napas.Untuk kasus yang lebih parah, infeksi dapat menyebabkan radang paru-paru atau kesulitan bernapas.Oleh karena itu, pengujian diperlukan untuk memastikan apakah terjangkit COVID-19 atau tidak ${ }^{11}$.

Virus COVID-19 dapat menular ke orang yang sehat melalui kontak langsung dengan percikan dari saluran napas orang yang terinfeksi yang keluar melalui batuk dan bersin. Orang juga dapat terinfeksi karena menyentuh permukaan yang terkontaminasi virus ini lalu menyentuh wajahnya (mis., mata, hidung, mulut).Virus COVID-19 dapat bertahan di atas permukaan benda selama beberapa jam tetapi dapat dibunuh dengan disinfektan biasa ${ }^{11}$.

Pada penyuluhan ini dijelaskan mengenai tatalaksana penanganan pasien sebelum terkonfirmasi COVID-19 bagi pribadi yaitu: menggunakan masker jika keluar dari rumah, menjaga jarak dengan keluarga, menerapkan etika batuk, alat makan dan minum segera dicuci dengan air/sabun, berjemur sebelum jam 9 pagi dan setelah jam 3 sore selama 10-15 menit, pakaian yang telah dipakai sebaiknya dimasukkan ke dalam kantong plastik atau wadah yang tertutup sebelum dicuci dan segera dimasukkan ke mesin cuci, mengukur dan mencatat suhu tubuh setiap jam 7 pagi dan jam 19 malam, sebaiknya saat dipagi hari membuka jendela kamar, membersihkan kamar setiap hari dengan menggunakan air sabun atau bahan desinfektan lainnya, memperhatikan ventilasi, cahaya dan udara di kamar ${ }^{12}$. 
Selain melakukan penyuluhan, dilakukan pula pembagian masker dan handsanitiser kepada peserta jamaah Mesjid Al-Hidayah Perumnas Antang, Kota Makassar. seperti pada Gambar 2.

Pembagian masker kepada jamaah masjid Al-Hidayah Perumnas Antang Kota Makassar, tentunya bertujuan untuk membangun kesadaran kepada masyarakat akan pentingnya untuk mencegah penularan COVID-19 dengan menggunakan masker dengan baik dan benar sehingga dapat menekan laju penularan infeksi COVID-19 di lingkungan rumah maupun di masyarakat.

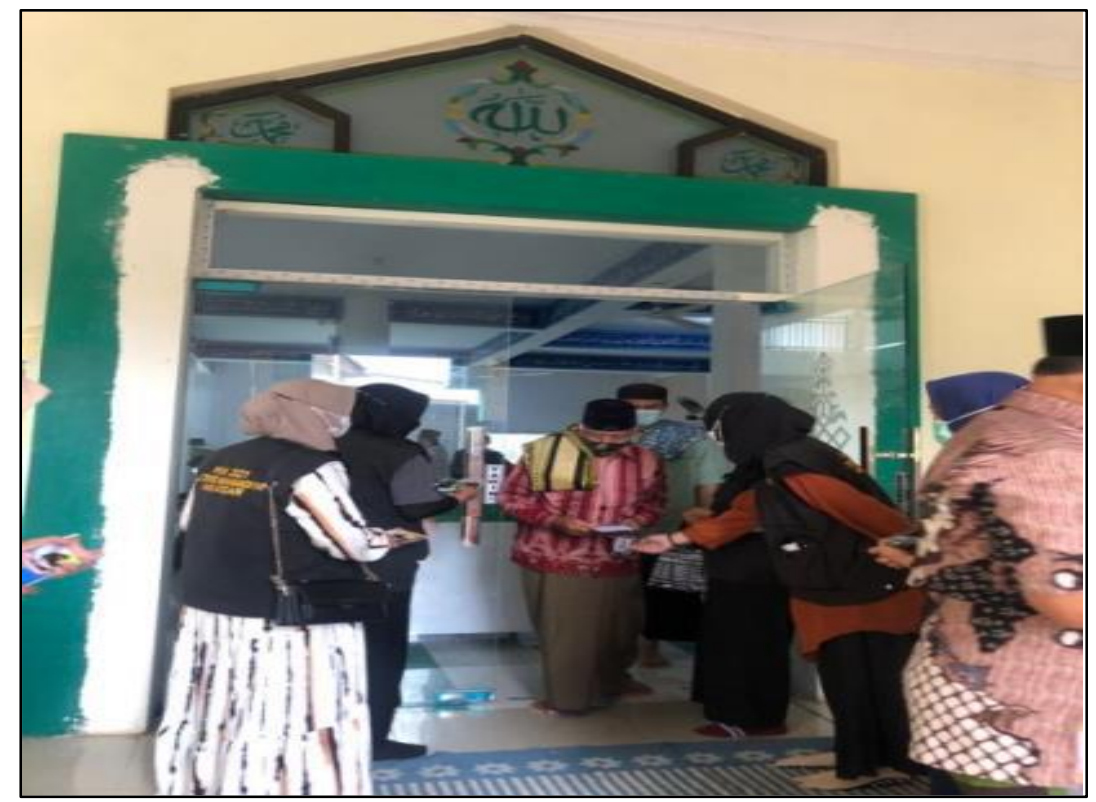

Gambar 2. Pembagian masker dan handsanitiser bagi peserta penyuluhan

Penting disadari bahwa penularan prasimtomatik COVID-19 terjadi karena adanya penyebaran virus melalui percikan yang dapat menyebabkan infeksi atau melalui sentuhan dengan permukaan benda yang terkontaminasi virus ini.Sehingga penggunaan masker medis adalah salah satu langkah pencegahan yang dapat membatasi penyebaran penyakit- penyakit saluran pernapasan tertentu yang diakibatkan oleh virus, termasuk COVID-1913.

Pada penyuluhan ini juga dijelaskan mengenai tata laksana penggunaan dan pembuangan masker dengan benar untuk memastikan masker tersebut efektif dan untuk menghindari peningkatan penularan. Beberapa informasi mengenai penggunaan tepat masker yang disampaikan pada penyuluhan ini antara lain: menempatkan masker dengan hati-hati, memastikan masker menutup mulut dan hidung, dan mengaitkan dengan kuat untuk meminimalisasi jarak antara wajah dan masker, menghindari menyentuh masker saat digunakan, 
melepas masker dengan teknik yang benar, tidak menyentuh bagian depan masker melainkan lepaskan masker dari belakang, setelah melepas atau setiap kali tidak sengaja menyentuh masker yang terpakai, membersihkan tangan dengan cairan antiseptik berbahan dasar alkohol atau sabun dan air mengalir jika tangan terlihat kotor, segera menggganti masker ketika masker menjadi lembap dengan masker baru yang bersih dan kering, tidak menggunakan kembali masker sekali pakai, membuang masker sekali pakai setelah digunakan dan segera buang setelah dilepas ${ }^{13}$.

\section{KESIMPULAN}

Dari kegiatan pengabdian masyarakat ini dapat disimpulkan bahwa peserta penyuluhan mengalami peningkatan pemahaman mengenai COVID-19 dan tata laksananya dimulai dari cara pencegahan, pengobatan dan komplikasinya.

\section{DAFTAR PUSTAKA}

Beiu, C., Mihai, M., Popa, L., Cima, L., \& Popescu, M. N. (2020). Frequent hand washing for COVID-19 prevention can cause hand dermatitis: management tips. Cureus, 12(4).

COVID, T. C. D. C., \& Team, R. (2020). Severe Outcomes Among Patients with Coronavirus Disease 2019 (COVID-19)-United States, February 12-March 16, 2020. MMWR Morb Mortal Wkly Rep, 69(12), 343-346.

Feng, S., Shen, C., Xia, N., Song, W., Fan, M., \& Cowling, B. J. (2020). Rational use of face masks in the COVID-19 pandemic. The Lancet Respiratory Medicine, 8(5), 434-436

Greenhalgh, T., Schmid, M. B., Czypionka, T., Bassler, D., \& Gruer, L. (2020). Face masks for the public during the covid-19 crisis. Bmj, 369.

Juwariyah, T., \& Priyanto, A. (2018). Hubungan tingkat pengetahuan dengan perilaku pencegahan kekambuhan luka diabetik. Jurnal Ners Dan Kebidanan (Journal of Ners and Midwifery), 5(3), 233-240

Kementrian Kesehatan Republik Indonesia, 2020, Pedoman Pencegahan Dan Pengendalian Coronavirus Disease (COVID-19), Direktorat Jendral Pencegahan Dan Pengendalian Penyakit.

Kementrian Kesehatan Republik Indonesia, 2021, Buku Saku Edisi Ke-2 Protokol Tata Laksana Covid-19. KEMENKES. Republik Indonesia.

Mona, N. (2020). Konsep Isolasi Dalam Jaringan Sosial Untuk Meminimalisasi Efek Contagious (Kasus Penyebaran Virus Corona Di Indonesia). Jurnal Sosial Humaniora Terapan, 2(2). Setiati, S., \& Azwar, M. K. (2020). COVID-19 and Indonesia. Acta Medica Indonesiana, 52(1), 84-89 Telaumbanua, D. (2020). Urgensi Pembentukan Aturan Terkait Pencegahan Covid-19 Di Indonesia. QALAMUNA: Jurnal Pendidikan, Sosial, Dan Agama, 12(1), 59-70. 
UNICEF, Maret 2020, Pesan dan Kegiatan Utama Pencegahan dan Pengendalian COVID-19 di Sekolah, UNICEF.

Yuliastuti, C., Novita, N. W., \& Narsih, S. (2014). Tingkat pengetahuan tb paru mempengaruhi penggunaan masker pada penderita tb paru. Journal of Health Sciences, 7(2). 